\title{
Comparison of Biological Wastewater Treatment Ability of Filter Media Made From Biomass Ash
}

\author{
Tahmina Sultana, Penjit Srinophakun, Umaporn Sanewirush and Pakamard Saewong
}

\begin{abstract}
Sustainable wastewater treatment is getting more attention worldwide. Researchers have been looking for cost effective and environment friendly technologies at the same time. For fish wastewater, nitrogen discharge limit is very high because of the regular fish-food leftover and wastes from fish. In this study, different types of biological filter media were used to host and grow nitrifying bacteria. The media made from biomass ash and coal bottom ash were tested in laboratory water treatment units in comparison with commercial media in terms of nitrogen compound removal. Under a given test condition of water temperature ranging from $26^{\circ} \mathrm{C}$ to $28^{\circ} \mathrm{C}$ and $\mathrm{DO}>4.00 \mathrm{mg} \mathrm{L}^{-1}$, the media made from biomass ash showed superior removal of nitrogen compounds and the toxic nitrogen wastes were removed within 16 days. In addition, scanning electron microscopic examination revealed that microstructural features of these media were suitable for growth of nitrobacteria, leading to improving nitrification performance.
\end{abstract}

Keywords - Biological treatment, Aerobic biological filter, Coal bottom ash, Porous pellets.

\section{INTRODUCTION}

Pollution related problems have become more attentive worldwide. Fish wastewater is an imperative source of water pollution. Normally it consists of oil and grease, salt and ammonia [1]. Biological treatment for removal of nitrogen waste is mainly focused among different treatment processes. Filter media are essential for this process, providing high surface area for bacteria to grow sufficiently for the reduction of toxic nitrogen compounds [2]. With the presence of functional micro organism, ammonia discharged to the system will be converted to nitrite $\left(\mathrm{NO}_{2}{ }^{-}\right)$and finally nitrate ion $\left(\mathrm{NO}_{3}{ }^{-}\right)$. This is called nitrification process [3]. The basic chemical conversions occurring this process by Nitrosomonas and Nitrobacter are expressed by,

$$
\begin{aligned}
& \mathrm{NH}_{4}{ }^{+}+1.5 \mathrm{O}_{2} \rightarrow \mathrm{NO}_{2}{ }^{-}+2 \mathrm{H}^{+}+\mathrm{H}_{2} \mathrm{O} \\
& \mathrm{NO}_{2}{ }^{-}+0.5 \mathrm{O}_{2} \rightarrow \mathrm{NO}_{3}^{-}
\end{aligned}
$$

At very low oxygen concentration, some species of functional bacteria utilize the oxygen in nitrate and convert it to nitrogen gas $\left(\mathrm{N}_{2}\right)$. This process is called denitrification.

Tahmina Sultana (Corresponding Author), Kasetsart University (KU), Bangkok, Thailand. Email: tahminaaust90@gmail.com

Penjit Srinophakun (Author), Kasetsart University (KU), Bangkok, Thailand. Email: fengpjs@ku.ac.th

Umaporn Sanewirush and Pakamard Saewong (Author), National Metal and Materials Technology Center (MTEC), NSTDA, Thailand. Email: pakamas@mtec.or.th
Compared with the regular biological nitrogen removal (nitrification- denitrification) process, biological filtration process is an energy-efficient and sustainable wastewater treatment technology [4].

Pumice as well as porous materials from nature, are being used widely and available in the market. In this study, pellets prepared from rice husk ash (RHA) and coal bottom ash (CBA) are introduced as alternatives of those conventional media. These porous media are characterized and compared their effectiveness on nitrogen compound removal with the commercially available pumice.

\section{EXPERIMENTAL PROCEDURE}

\section{A. Media Preparation}

The research was conducted at the Pilot plant of National Metal and Materials Technology Center (MTEC), NSTDA, Thailand. RHA and CBA media were prepared from RHA and CBA by mixing a ready mix ash precursors with water, shaping and firing at around $1100^{\circ} \mathrm{C}$ for 1hour [5] while pumice was purchased from the market, crushed and size selected to $4-12 \mathrm{~mm}$.

\section{B. Testing Unit Setup}

To prepare a recirculation water flow system, a 2 and 27 liter plastic boxes were used as a media container and a water tank, respectively. The water was circulated by a pump, which was fixed at the bottom of the water tank, to the media container and returned to the tank via PVC pipes (Fig. 1). 4 different sets were prepared for this study: 1) with RHA, 2) CBA 3) pumice and 4) without media. Each set had 4 duplicates. Every water tank of each duplicate was filled with 20 liters of water and the set with media was added with 1 liter of media.

\section{C.Material Characterization}

Density of the media was measured by Achimedes' method. While for the micro-structural observation, the samples were gold coated and examined in a scanning electron microscope (SEM). Surface area of each media was estimated by measuring the pore size at the surface of the media and using spherical equivalent method. 


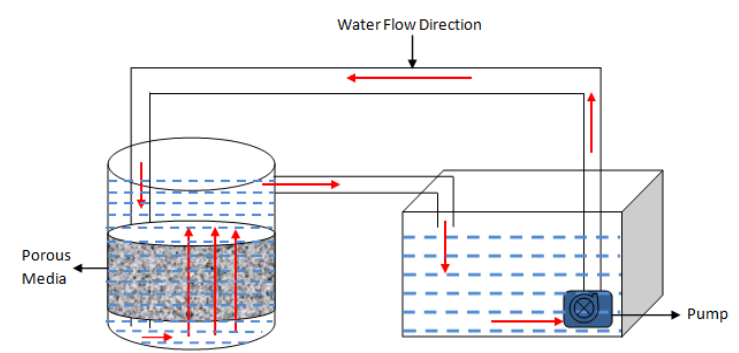

Fig. 1 Testing unit setup

\section{Water Treatment Testing}

15 grams of fish food was added in each tank for all experiment sets and the concentrations of total ammonia $\left(\mathrm{NH}_{3} / \mathrm{NH}_{4}{ }^{+}\right)$, nitrite $\left(\mathrm{NO}_{2}{ }^{-}\right)$, and nitrate $\left(\mathrm{NO}_{3}{ }^{-}\right)$were regularly measured using test kit and $\mathrm{pH}, \mathrm{DO}$ and temperature were monitored by portable devices.

\section{RESULTS AND DISCUSSION}

\section{A. Media Properties}

The densities and surface area are given in table I, surface area of RHA is greater than others, while those of CBA and pumice are of the same range.

TABLE I

MEDIA PROPERTIES

\begin{tabular}{|c|c|c|c|}
\hline $\begin{array}{c}\text { Bio filtering } \\
\text { media }\end{array}$ & $\begin{array}{c}\text { Packing } \\
\text { Density }(\mathbf{K g} / \mathbf{L})\end{array}$ & $\begin{array}{c}\text { Bulk } \\
\text { Density }\left(\mathbf{g} / \mathbf{c m}^{\mathbf{3}}\right)\end{array}$ & $\begin{array}{c}\text { Surface } \\
\mathbf{a r e a}\left(\mathbf{m}^{2} / \mathbf{L}\right)\end{array}$ \\
\hline RHA & 0.57 & 0.89 & 32.7 \\
\hline CBA & 0.51 & 1.09 & 17.2 \\
\hline Pumice & 0.31 & 0.69 & 15.7 \\
\hline
\end{tabular}

\section{B. Microstructure of the Media}

Fig. 2 - 4 show microstructures of the RHA, CBA and pumice, respectively before and after treatment. It is evident that microorganisms are found intensively across the observed surface of all media after treatment.

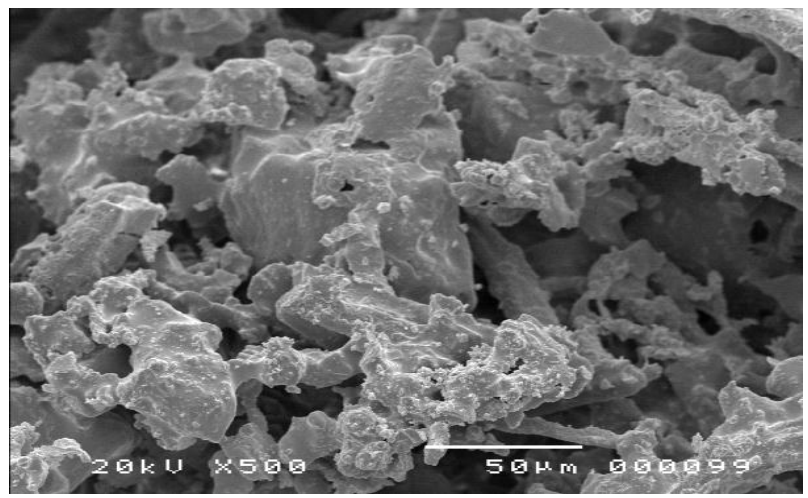

(a)

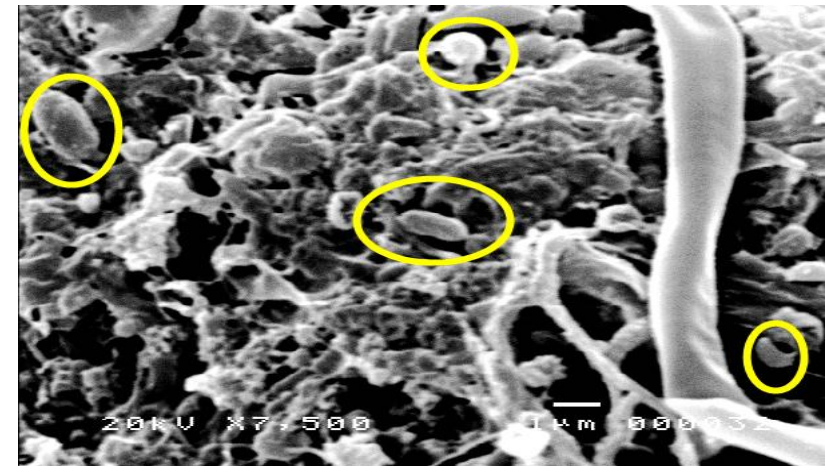

(b)

Fig. 2 RHA surface (a) before (b) after the treatment. Circles indicate the presence of the functional microorganisms.

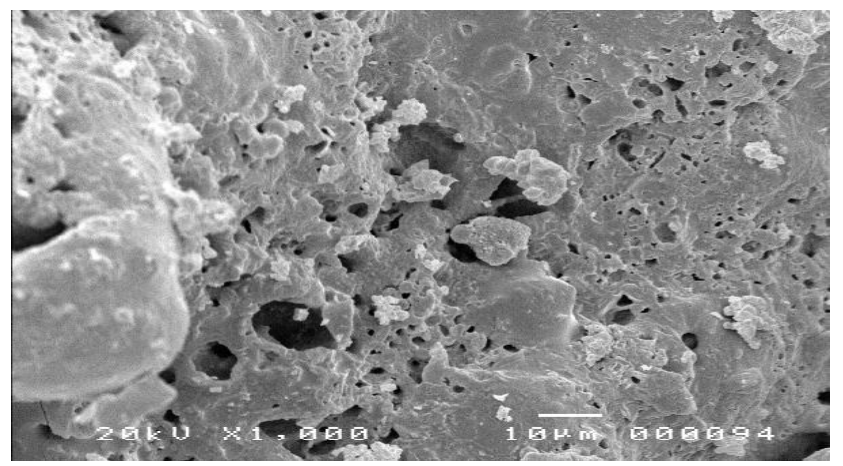

(a)

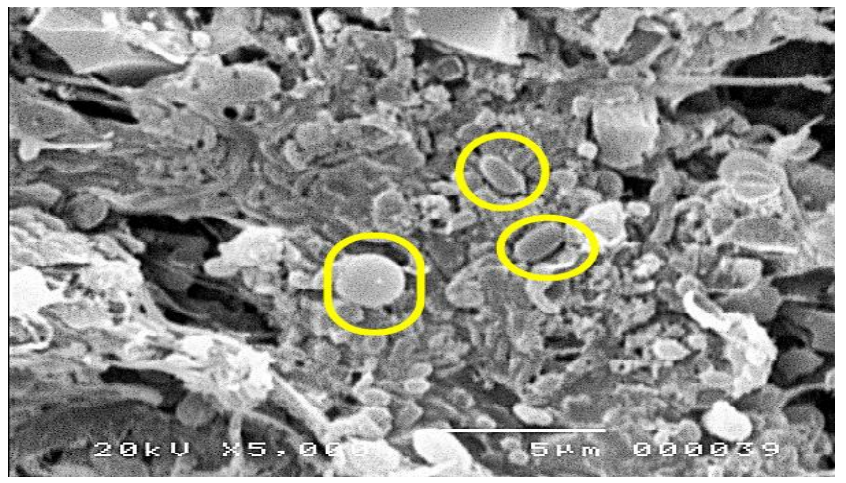

(b)

Fig. 3 CBA surface (a) before (b) after the treatment. Circles indicate the presence of the functional microorganisms.

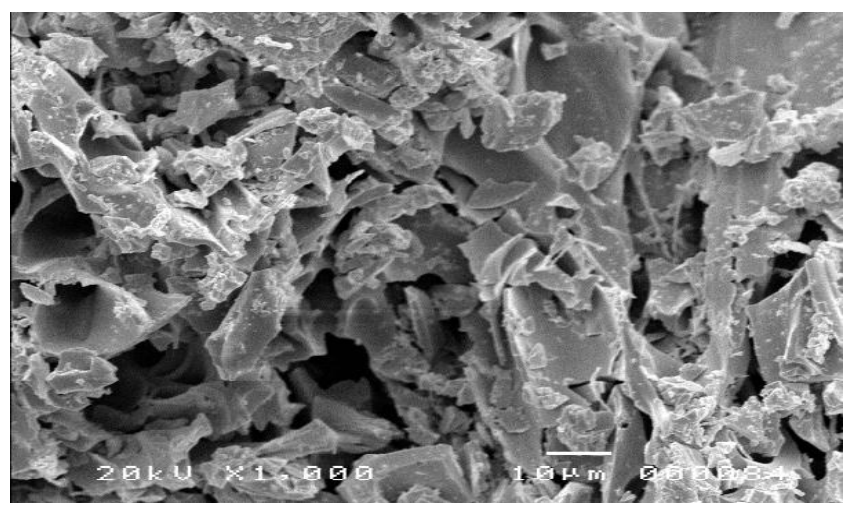

(a) 


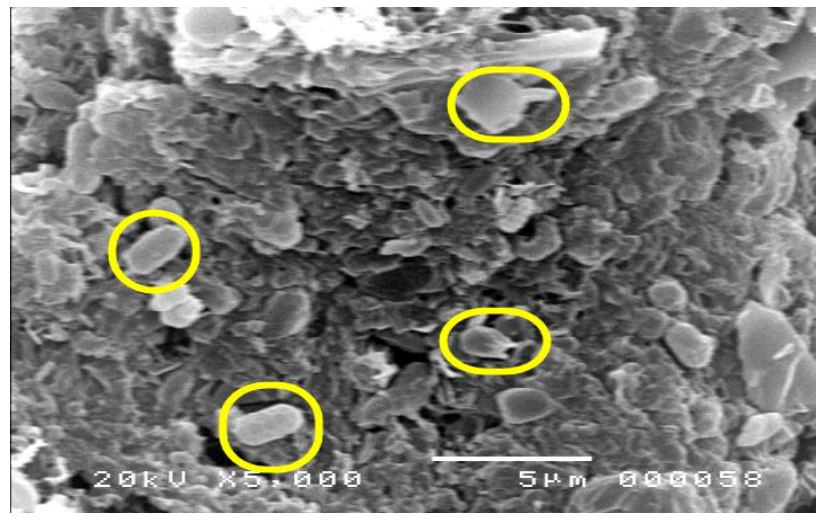

(b)

Fig. 4 Pumice surface (a) before (b) after the treatment. Circles indicate the presence of the functional microorganisms.

\section{Water Quality}

It was found that $\mathrm{pH}, \mathrm{DO}$ levels and temperature for all sets varied from 7 to $8.2,8.17$ to 8.42 and $27^{\circ} \mathrm{C}$ to $30^{\circ} \mathrm{C}$ respectively, which is in suitable ranges for nitrification process to take place [3].
Average concentrations of total ammonia, nitrite and nitrate of water are given in Figs 5, 6 and 7, respectively. All sets show increasing levels of total ammonia, $\mathrm{NO}_{2}{ }^{-}$and $\mathrm{NO}_{3}{ }^{-}$with time to the maximum values. When nitrification process commences, with the presence of microorganisms, the concentrations of toxic nitrogen compounds reduce to minimum values. So nitromonas bacteria can convert ammonia to nitrite and nitrobacteria can convert nitrite to nitrate in nitrification process. Autotrophic denitrification and anaerobic ammonium oxidation process helps nitrate to convert to gaseous nitrogen compound including denitrogen [6]. From the micrographs after the treatment, not only the expected functional bar shaped cells, but also various types of microorganisms are found. Species identification will be carried out further if those play a role in the treatment process.

From these results it is clear that the RHA and CBA show a comparable treatment performance to the pumice. Nitrification process occurs in the set without media also, but it takes 7 days longer than those with the media.

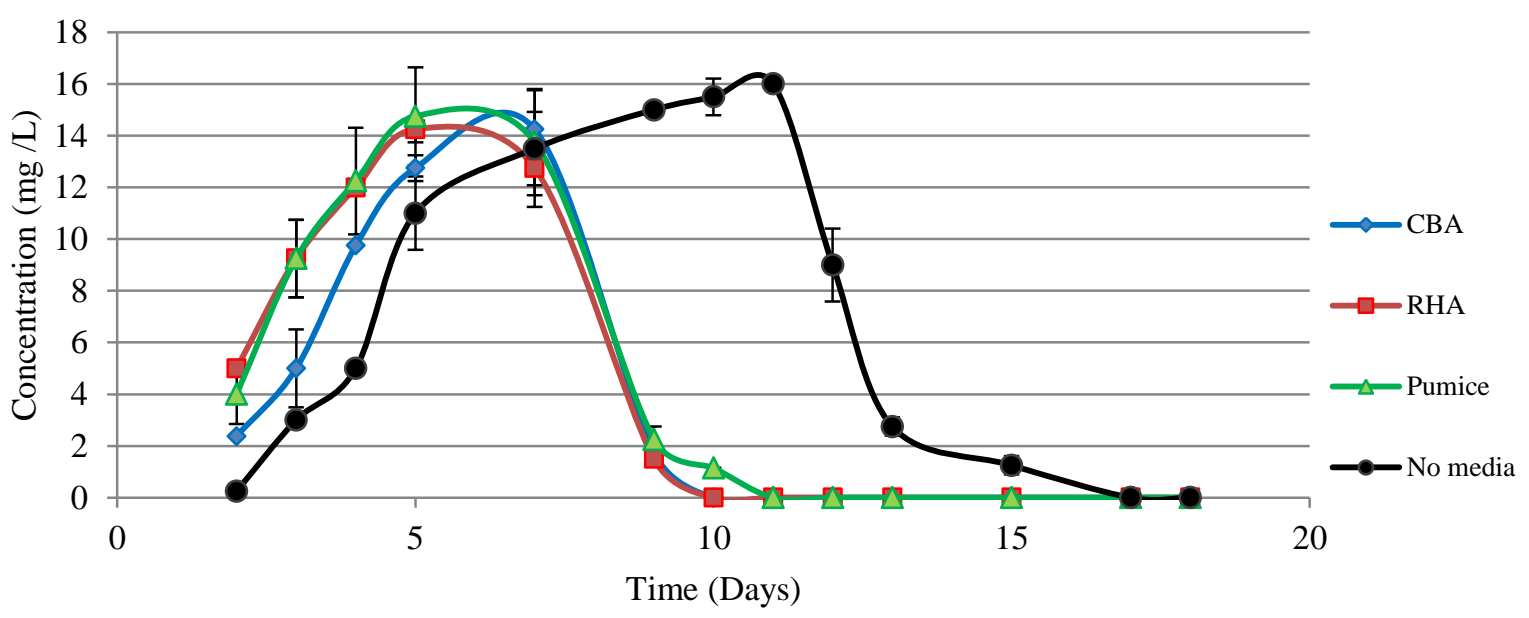

Fig. 4 Change of total ammonia concentration with time for all sets.

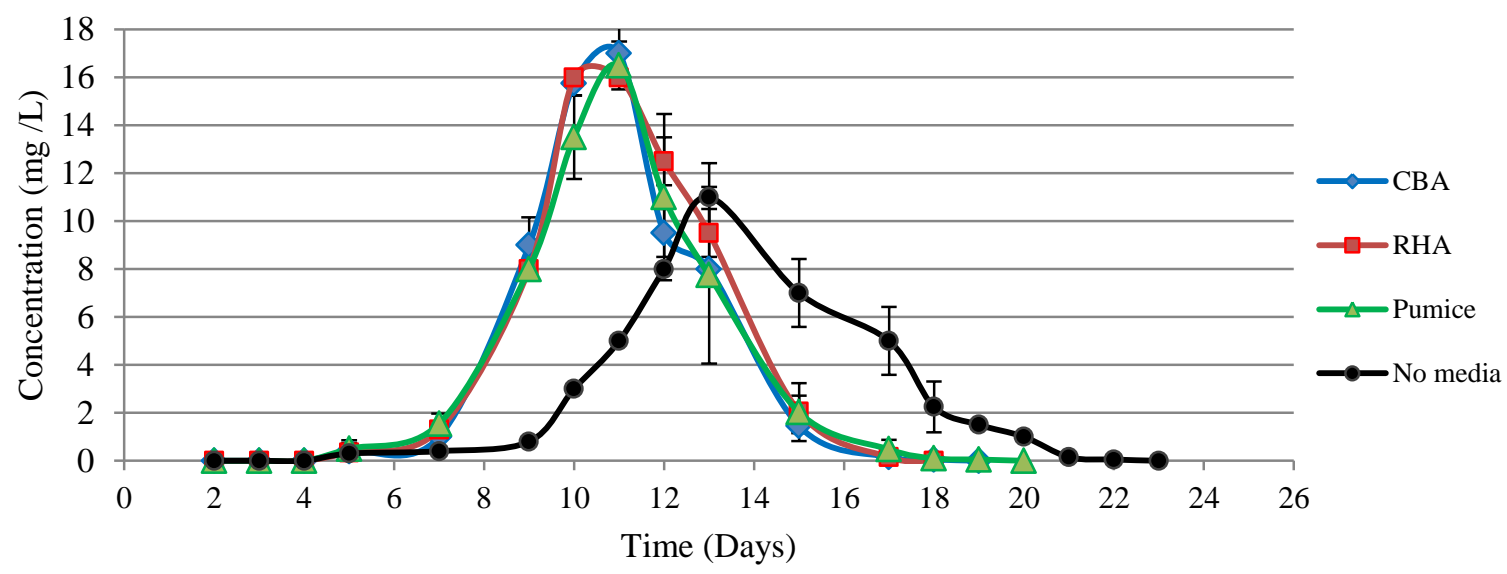


Fig. 5 Change of nitrite concentration with time for all sets.

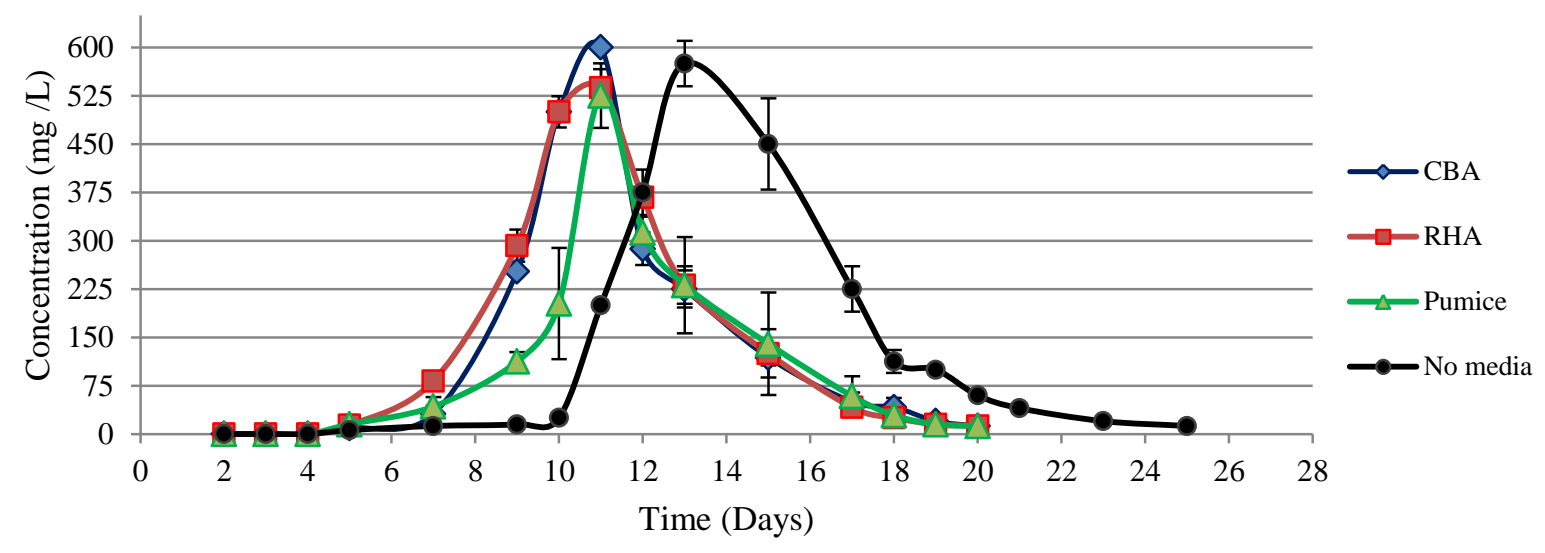

Fig. 6 Change of nitrate concentration with time for all sets.

\section{CONCLUSION}

The media made from rice husk ash and coal bottom ash can be an alternative of the media from irreversible source. The removal of nitrogen compound is found almost same in those pellets. Future study on identification of bacterial species is recommended.

\section{ACKNOWLEDGMENT}

The authors wish to thank the Chemical Engineering department of Kasetsart University (KU), Thailand Advanced Institute of Science and Technology (TAIST) program and Metal and Materials Technology Center (MTEC), National Science and Technology Development Agency (NSTDA), Thailand for their laboratory facilities and financial support.

\section{REFERENCES}

[1] N. Sunny and L. M. P, "Physiochemical Process for Fish Processing Wastewater," Int. J. Innov. Res. Sci. Eng. Technol., vol. 2, no. 4, pp. 901-905, 2013.

[2] D. S. Chaudhary, S. Vigneswaran, and H. Ngo, "Biofilter in Water and Wastewater Treatment," Korean J. Chem. Eng., vol. 20, no. 6, pp. 1054$1065,2007$.

[3] J. M. Ebeling, "Biofiltration- Nitrification Design Overview," 2006.

[4] E. Trikoilidou, G. Samiotis, D. Bellos, and E. Amanatidou, "Sustainable operation of a biological wastewater treatment plant," in 20th Innovative Manufacturing Engineering and Energy Conference, 2016.

[5] B. Suchatjaroenying, U. Senewirush, and P. Seawong, "Feasibility study of the use of rice husk ash pellets for Bio-filtration," in International Conference on Green and Sustainable Innovation, 2009, no. RC05.

[6] D. Han, H. Yun, and D. Kim, "Autotrophic nitrification and denitrification characteristics of an upflow biological aerated filter," $J$. Chem. Technol. Biotecnol., vol. 1116, no. July, pp. 1112-1116, 2001. 